\title{
UWAGI O PRACY NAD TŁUMACZENIEM SW. AUGUSTYNA
}

Jeszcze na długo przed rozpoczęciem pracy nad przekładem "Wyznań" św. Augustyna medytowałem nieraz nad słynnym zdaniem, jakie pada niemal na samyn początku tej sławnej księgi: "Fecisti nos ad te et inquietum est cor nostrum, donec requiescat in te" ${ }^{1}$. Dlaczego: ad te, a nie: Tibi? To przecieź musi coś oznaczać, ta przyimkowa składnia, posługująca się przyimkiem wyrażającym kierunek w przestrzeni. U takiego stylisty jak Augustyn, nie jest to jeno zjawisko charakterystyczne dla późnej łaciny; jest to z pewnością element brzemienny w sens. Zrozumiałem, iz mówi się tu o stwarzaniu nie d 1 a $s i$ e 1 , ale $k u$ s o b 1 e, stwarzaniu istot skierowanych w swej egzystencj 1 ku celowi, istot nie nieruchomych, ale będacych nieustannie w drodze. Nawet przypomniało mi się tu powiedzenie Księg1 Mądrości o tym, iz "mądrość jest najgłębszaz ze wszystkich rzeczy, jakie sie ruszajă, 1 dociera wszędzie" /Mdr 7, 24/. Tak samo "serce nasze" porusza sic, jest szybkie.

Nad inna Praza "Wyznaí" medytowałem jeszcze dłuźej. Chodzi tu o miejsce, w któryin Augustyn zwraca się do Miłości Anor: "Amor meus, in quem deficio, ut fortis sim"2. Co oznacza to "deficio", przed któryin pada tak niezwykłe, tak lokalnie określone "In quen"? Niegdyś przełożyłem to tak: "dla której staję się słaby, aby się wzmocnić" - ale czułem, że to nie jest to, co być powinno, że to miejsce jeszcze nie jest przezoźone. Dopiero przy trzecim wydaniu "Wyznań", tym, które się niedawno ukazało, jakby mię olśniło światło. Napisałem: "Miłosci moja, do której się garnę, abym nabył mocy". - Tak, "garnę się", tym skwapliwym, bezbronnym, ale 1 pelnym determinacji ruchem, jakim się dziecko garnie do kolan matki. Bezbronność ta jest w słowie

1 Confessiones I $1, \operatorname{CSEL} 33,1$, tłum. Z. Kubiak /Sw. Augustyn, Wyznania, Warszawa $1983^{3} \% 7$.

2 Confessiones III 6, CSEL 33, 52, Kubiak 51. 
"deficio", w którym widzimy zarazem obraz pochylania sie, przypadania w dót, jakby do kolan.

Jeszcze inny przykład ... Nie, juz nie będę go wymieniał. lus lałbym cytować nieskoúczoność. Czy w ogóle są w "Confessiones" takie zdania, nad którymi nie medytowałem, do których nie wracałem, nieraz budząc sie w głębi nocy, gdy mię we śnie nawiedziło długo szukane rozstrzygnięcie? Niewiele jest zdań, których nie tropiłem z takim trudem. Praca ta była podobna do wspinaczki górstieje

Niegdyś, rozpoczynając ośmioletnią pracę nad tym przekładem, stawiałem sobie jako zadanie, żeby przezwyci ̨żý́ otchłaú półtora tysiąca lat: chodziło mi o to, by "Wyznania" przenówiły do czytelnika jako dzieło dziś w petni aktualne. Niebawem jednak zrozumiakea, że o to wcale sio nie trzeba szczególnie starać. Wystarczy tylko być wiernym i ścisły!n. Dla takich dzieł, jak to, nie istnieje przepaśc czasu.

Trudnościa prawdziwaz byizo odtwarzanie tej nadnaturalnej gesstości, jakiz w owym tekście osiaga ludzka mora. Staje się ona jakby przemienioną substancją: jakby z drewna stawała się metalem. Inny ma blask, inny dźwięk, inną twardość. Najbardziej zadziwia wtedy, gdy we erazach najprostszych usuwa nam spod nóg grunt, do którego przywykliśay; gdy zmusza nas do wispinania się coraz wyżej. "Pałamy i idziemy" - czytamy w którymś miejscu "wyznań"3.

\section{Zygmunt Kubiak - Warszawa}

\section{ALCUNE OSSERVAZIONI SULLA TRADUZIONE DELLE OPEIE DI} SANT ${ }^{\circ}$ AGOSTINO

/Riassunto/

L'Autore, noto traduttore polacco delle "Confessioni" di Sant'Agostino, fornisce qualche osservazione sulla traduzione di quest'opera.

3 Por. Confessiones XIII 9, CSEL 33, 352, Kubiak 343. 